\title{
Digitization, return, and circulation of sound recordings among the Bora in the Colombian Amazon
}

Digitalização, retorno e circulação de registros sonoros entre os Bora na Amazônia Colombiana

Numérisation, retour et circulation des enregistrements sonores chez les Bora d'Amazonie colombienne

Maria Luísa Lucas

\section{OpenEdition}

\section{Journals}

Electronic version

URL: https://journals.openedition.org/jsa/18640

DOI: $10.4000 /$ jsa. 18640

ISSN: 1957-7842

\section{Publisher}

Société des américanistes

\section{Printed version}

Date of publication: 15 December 2020

Number of pages: 151-176

ISSN: 0037-9174

Electronic reference

Maria Luísa Lucas, "Digitization, return, and circulation of sound recordings among the Bora in the Colombian Amazon", Journal de la Société des américanistes [Online], 106-2 | 2020, Online since 30 December 2020, connection on 16 September 2022. URL: http://journals.openedition.org/jsa/18640 DOI: https://doi.org/10.4000/jsa.18640 


\title{
Digitization, return, and circulation of sound recordings among the Bora in the Colombian Amazon
}

\author{
Maria Luísa LuCAS *
}

This paper aims to present and discuss a case of return (or repatriation) of sound files among the Bora in the Colombian Amazon. Particular emphasis will be given to the ritual songs. Thus, we will examine how these song files have returned to their original places, as well as the access arrangements that affect them and how they are currently used. Such ethnographic data will reveal essential questions about the transmission of knowledge and the master-apprentice relationship. Following recent discussions on sound repatriation, I will discuss how new technologies can, on the one hand, rekindle relationships and help recover lost content but, on the other hand, might cause sickness and danger. [Key words: Colombian Amazon, digital repatriation, People of the Center, Mireille Guyot, Bora.]

Digitalização, retorno e circulação de registros sonoros entre os Bora na Amazônia Colombiana. O objetivo desse artigo é apresentar e discutir um caso de retorno (ou repatriação) de registros sonoros entre os Bora na Amazônia Colombiana. Um interesse particular será dirigido aos cantos rituais. Assim, nós entenderemos como essas canções retornaram e foram recebidas em seus locais de origem, bem como quais são os regimes de acesso que lhes foram aplicados e como elas são utilizadas hoje em dia. Tais dados etnográficos trarão à tona questões importantes sobre a transmissão de saberes e sobre a relação entre mestres e aprendizes. Em consonância com discussões recentes sobre a repatriação sonora, nós entenderemos ainda como as novas tecnologias podem, de um lado, reativar relações e recuperar conteúdos perdidos e, de outro, provocar adoecimento e perigo. [Palavras-chave: Amazônia Colombiana, repatriação digital, Povos do Centro, Mireille Guyot, Bora.]

Numérisation, retour et circulation des enregistrements sonores chez les Bora d'Amazonie colombienne. Le but de cet article est de présenter et de discuter en détails un cas de retour (ou de rapatriement) d'enregistrements sonores chez les Bora en Amazonie colombienne. Un intérêt particulier est porté aux chants exécutés lors des rituels. Ainsi, nous apprenons comment ces chants ont retrouvé leurs lieux

* Post-doctoral researcher at the Musée du quai Branly - Jacques Chirac (2019-2021) and associate researcher at the Laboratory of Anthropology of Art, Ritual and Memory (LARMe, PPGAS, Museu Nacional) [marialuisalucas@gmail.com]. 
d'origine, comment ils y ont été reçus, à quels régimes d'accès ils ont été soumis et de quelle manière ils sont actuellement utilisés. De telles données ethnographiques soulèvent des questions importantes sur la transmission des savoirs et la relation maître-apprenti. Tel que les récentes réflexions sur le rapatriement sonore l'ont montré, cela permet de comprendre comment les nouvelles technologies peuvent, d'une part, raviver les relations et permettre de récupérer des contenus perdus mais, d'autre part, risquent aussi de déclencher des maladies et de susciter du danger. [Mots-clés : Amazonie colombienne, restitution numérique, Gens du Centre, Mireille Guyot, Bora.]

Mireille Guyot was a Franco-Swiss anthropologist who, from 1969 to 1984, worked with the so-called "People of the Center" (Gasché 2009; Echeverri 1997), especially the Bora and the Miraña who live in the Caquetá-Putumayo area (Colombia) and along the Ampiyacu River (Peru). Through various research programs, Guyot's work over the years has focused on the systematic collection of information on the populations of this region. ${ }^{1}$ In a paper published in the Journal de la Société des américanistes, Guyot comments how the Bora in the Igaraparaná River, on the eve of a ritual, asked for her permission to listen to some of the songs she had recorded months before in malocas (communal houses) on the Cahuinari River:

The Bora had invited around one hundred and fifty people [...] and the men, when they got up in the morning or at night before going to sleep, softly rehearsed the pijo? pa songs, which are among the most popular of their repertoire. This was probably the time when my role as an ethnologist proved most positive. The pijo?pa songs that I was able to record during my stay in the Cahuinari region pleased [the people in the Igaraparaná]. They asked me to listen to them many, many times, and quickly learned the songs in order to perform their ritual. (Guyot 1972, p. 145; my translation $)^{2}$

I am sure that neither the anthropologist nor the Bora imagined that more than 45 years later, the Bora would rediscover these records and have access not only to part but to all of the sound recordings made at that time. This happened thanks to a fund of archives in custody of the Laboratoire d'ethnologie et de sociologie comparative (LESC) at the université Paris Nanterre. ${ }^{3}$ The "Fonds Guyot,"

1. At the time, the data collection by the anthropologist was sponsored by the Fonds national suisse de la recherche scientifique and the Centre national de la recherche scientifique (CNRS, France). Later, some photos, sound files, and artifacts collected in these missions were incorporated into museum collections linked to the research funders (especially the Musée de l'Homme and the Musée d'ethnographie de Bâle). On the subject, see Gabus (1975) and Gasché, Lourteig, and Centlivres (1976).

2. On the pijo?pa (or píchojpa) ritual, see Lucas (2019, p. 341).

3. The Fonds Guyot's digitization and repatriation process was funded with Legs Lelong grants from the INSHS (CNRS). I am especially grateful to Jean-Pierre and Bonnie Chaumeil, 
currently stored in the LESC's Bibliothèque d'ethnologie Eric-de-Dampierre, allows access to a collection of over 600 written documents, including field notebooks, research notes, and institutional and personal letters. In addition, it has approximately 1,880 visual images (including photos, negatives, and slides), and 215 audio files recorded on magnetic tapes which, together, add up to about 25 hours of sound recordings. ${ }^{4}$ For decades, the populations documented were unaware of the existence of this material, even though they still have clear memories of Guyot's passage through the region and of her recording activities. I studied this collection in the course of my $\mathrm{Ph}$. D. research and, motivated by both academic and ethical considerations, endeavored to return copies to the source communities.

This paper, which is basically ethnographic, focuses on the audio files generated from the digitization of the magnetic tapes recorded by Mireille Guyot and on the subsequent process of return or "digital repatriation" of the material to the Bora living on the Igaraparaná River. ${ }^{5}$ Although reflections concerning the simultaneous return of the photos and transcriptions of the Fonds Guyot to the communities involved would also be of interest, I consider that a specific focus on the return of audio files among the Bora can contribute to the increasingly prominent debate on sound repatriation.

\section{Sound repatriation}

Repatriation of artifacts and indigenous presence in the museums have been subjects of reflection within and outside the academy over recent decades. Moreover, in this period they have generated meaningful discussions involving metropolitan museum institutions and imbricated political-diplomatic negotiations. ${ }^{6}$ Good recent reviews of repatriation actions and the dialogue between native communities, museums, and the State are found in Peers and Brown (2003), Echo-Hawk (2002), and Sarr and Savoy (2018). In Lowland South America, however, actions of this kind are still modest — which is revealed

Philippe Erikson, Valentina Vapnarsky, Joséphine Simonnot, and Frédéric Dubois for providing me with access to this material and making the digitization process possible.

4. Such magnetic tapes are presented in roll form. Older than magnetic tapes in cassette format, such media are played on reel-to-reel tape recorders. The numbers presented here are based on the amount of digital files generated from the digitization process.

5. In the following, I will deliberately oscillate between the terms "return" and "repatriation." Whenever I use the latter, I keep in mind something similar to Antony Seeger's definition: "I use 'repatriation' to refer to the return of music to circulation in communities where it has been unavailable as a result of external power differences - often the result of colonialism, but also including differential access to wealth and technology, educational training, and other factors" (2019, p. 145).

6. See, among many others, Ames (1992) and Simpson (1996, 1997). 
by the small number of authors who have discussed the subject. Examples of pioneering works dealing with the repatriation of artifacts among the indigenous peoples of South America are Rubenstein (2007), regarding the Shuar shrunken heads, Iphan (2007) and Martini (2012), for artifacts on the Upper Rio Negro, and Melo (2010) about the restitution, in the 1980s, of a krahô ritual axe. More specifically, repatriation initiatives aimed at returning sound archives to indigenous peoples have been conducted mostly in Australia (Lancefield 1998; Toner 2003; Treloyn, Martin and Charles 2016), Africa (Nannyonga-Tamusuza and Weintraub 2012; Thram 2019; McCoy 2019) and North and Central America (Valdovinos 2017; Reed 2019; Jaakola and Powell 2019). ${ }^{7}$ Although they do not necessarily address the issue of repatriation, we have seen the emergence in recent years of works such as those by Heurich (2018), Cesarino (2019), and Seeger (2019) on the relationship of indigenous people in Lowland South America with sound recordings (especially those made on digital media).

This relative lack of works on the subject in South America contrasts with the range of travelers and investigators who, over the last century, made audio recordings among the indigenous peoples of this region. Very often, these investigators, whose research makes great use of records collected in the field, did not provide their interlocutors with copies or uncomplicated means of access to the recorded material. They were not concerned with keeping accurate inventories of either the exact places and contexts of collection or the people recorded. It is notable how today this scenario has undergone a profound transformation due to technological advances and the demands of local indigenous organizations in the face of investigators' work. However, there is still an extensive amount of sound material collected in the South American Lowlands scattered in museums, universities, and private collections.

When we turn to the repatriation of indigenous artifacts, we notice that one of its primary effects is a double inversion or deviation from the usual sense of circulation of these objects (Appadurai 1988). Taken at first from their communities of origin and incorporated into public or private collections, when they arrive again at the place they came from, they make the return from the metropolis to the periphery. Nevertheless, this is not to say that this return restores or re-establishes exactly the circulation that the artifacts experienced within the indigenous communities or museums. As we know, one of the main consequences of repatriation is that it endows the returned objects with previously non-existent meanings and use value. Transformations of this kind also seem to happen when audio records are returned. However, there is a significant detail that has a direct impact on the circulation of the repatriated

7. It is important to note that several of these articles are published in the Oxford Handbook of Musical Repatriation recently organized by Gunderson, Lancefield and Woods (2019). 
sound material. Usually, it returns to its original location in the form of virtual copies stored in digital devices.

Therefore, instead of wax cylinders or magnetic tapes, today, the intermediaries of the sound record repatriation processes use external hard drives, flash drives, microSD cards, or even "cloud" file storage servers. The merely audio record in old media (such as magnetic tapes or cassettes) already gave rise to debate about, among other things, the consequences of the creation of a sterile sound image. Then, the record would dismember what Menezes Bastos (2007) defines as the "intersemiotic chain" of the ritual, in which music, although playing a central role, is invariably associated with verbal arts, and plasticvisual and choreological expressions. Nowadays, digital media introduce at least one new issue: the possibility of profoundly transforming the senses and the speed of circulation of these recordings - which in turn would also impact the transmission of the knowledge contained or made evident by them. Thus, to reproduce sound files, indigenous peoples no longer need to have access to expensive and hard-to-maintain equipment such as phonographs or reel-to-reel tape recorders. Instead, they can play back the repatriated records on low-cost mobile phones, computers, and portable speakers that proliferate in several communities today. This transformation in how the recordings of ritual songs and mythical narratives in the Fonds Guyot are stored and circulated was at the heart of the debates on the return process that I will describe below' This transformation in how the recordings of ritual songs and mythical narratives from the Fonds Guyot are stored and circulated was at the heart of the debates on the return process that I will describe below.

\section{The return of the Fonds Guyot audio files}

I first had access to the Fonds Guyot in 2015 during a brief visit to the Université Paris-Ouest Nanterre La Défense (which has since then been renamed "Université Paris Nanterre"). The following year, during a local indigenous council on the Igaraparaná River, I shared with my interlocutors the little that I then knew about the existence and content of this archive. At the same meeting, the Bora drew up a document, appointing me as the intermediary in the initiative to return copies of the material to them.

At that point, the Bora did not request the original documents and records to be returned to their communities. Instead, they claimed that the institution where the material was stored (in this case, the university) was responsible both for granting them access to it and for keeping it in the best condition. In their speeches, the Bora considered that this was an opportunity to recover songs and narratives from their ancestors and, at the same time, to arouse in young people some interest in knowledge considered "traditional" or "deep" (see below). 
In 2016, I spent a few months working on the digitization of the Fonds Guyot in Paris, and the following year I returned to Igaraparaná with dozens of microSD cards and flash drives to hold a first community meeting with the maloca chiefs and several other cabildo leaders. The cabildos are a kind of public institution widespread in the Colombian indigenous landscape. Their "governors," elected by vote, are responsible for communication between the communities and the State. On the other hand, maloca or roundhouse chiefs are the male first-borns of the clan's main lineages who enjoy a social status considered "prestigious" or "noble" (Lucas 2019). After they read and signed the delivery contract prepared by the university (Figure 1), I commented on what I had found in the archives. I provided each leader present with a digital copy of all the material. Together, we concluded that I would make several visits in the coming months to deliver other digital copies to those families whose ancestors had, to a greater or lesser degree, participated in Guyot's recordings. However, I had one concern: could I deliver all the records to all these families, since I risked putting them in contact with recordings made with people who were not considered their direct relatives?

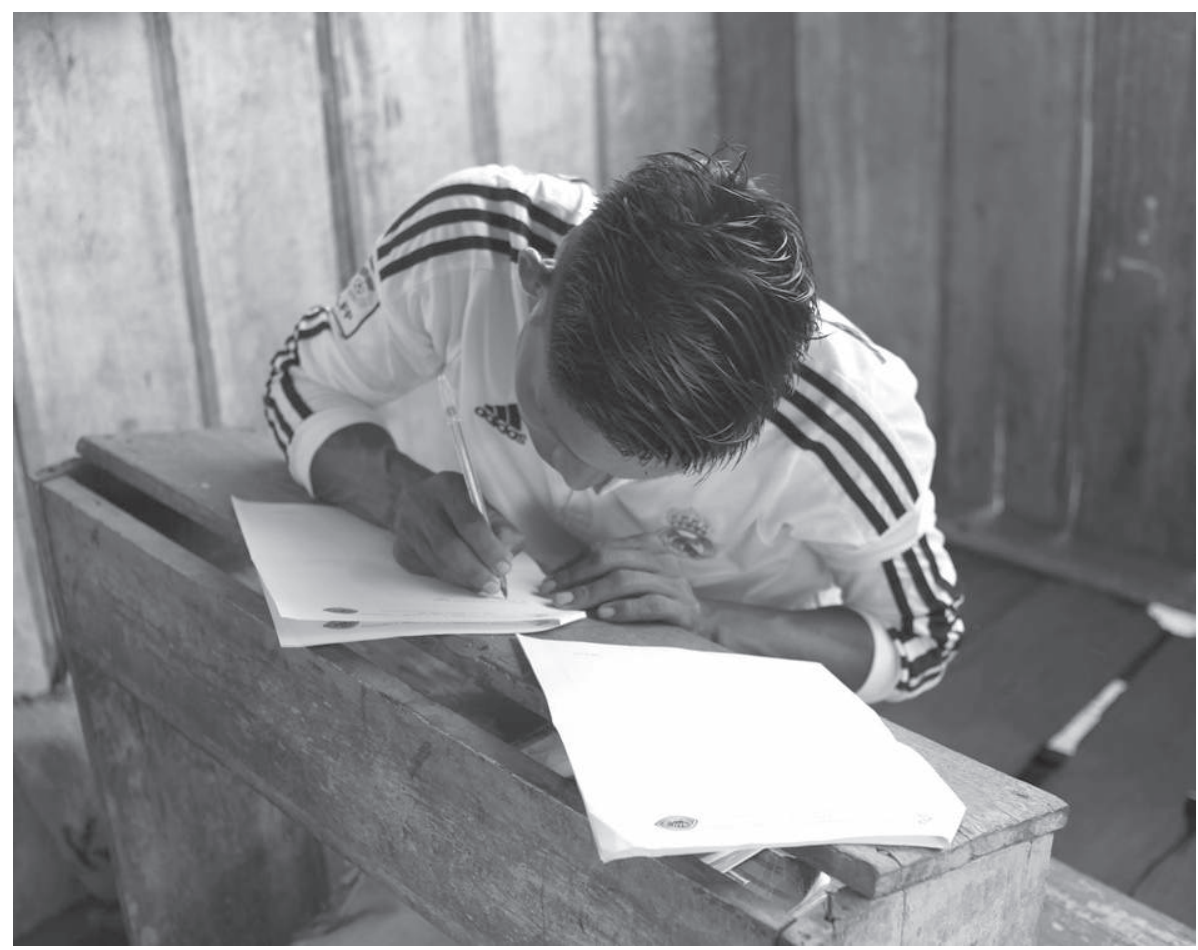

Fig. 1 - James Kuguao, "governor" of the Petani cabildo, signing the Fonds Guyot's delivery contract (photo M. L. Lucas, May 5, 2017) 
To this inquiry, the Bora responded that the decision to request access had been taken collectively at the aforementioned community council. Therefore, according to them, the records should be shared with all. As we will see below, the deliberations regarding access have become more evident as the material has been disseminated among the different communities. On the same occasion, I informed them that the counterpart to the digitization of sound recordings by the Centre de recherche en ethnomusicologie (CREM) ${ }^{8}$ was the inclusion of the material in an online database whose access arrangements should be discussed and agreed with the local communities. ${ }^{9}$ To me, this information made clear how there were two different (but not conflicting) sets of interests in play.

In the first place, both the research center and I saw in the repatriation a possibility to generate metadata that could complement the information that Guyot had gathered for each of the magnetic tapes. That would be the opportunity, for example, to learn which songs were associated with which of the different Bora rituals, and also to identify singers, narrators, and which musical instruments had been used. On the other hand, my interlocutors triggered an idea, widely spread among different indigenous peoples, according to which repatriation is a mechanism for revitalizing cultural practices endangered or in decline. Simpson, who considers the repatriation of museum artifacts "the form par excellence of cultural preservation" $(2009$, p. 129), argues that the return of objects can be a kind of individual and collective "cure" of problems that affect some native communities:

At an individual level healing may involve "overcoming personal problems that are debilitating to community life." This can include alcohol or other forms of substance abuse as well as "negative emotions and behavior such as jealousy or anger." The revival of cultural and ceremonial practices can provide opportunities for individuals to reconnect with meaningful aspects of traditional culture and contribute to the process of personal healing. (Simpson 2009, p. 125)

The author, here, has in mind the objects generally related to the practices of colonial despoliation (and not sound records obtained by researchers). Even so, the Bora would partially agree with Simpson, since they consider that the return of the songs collected by Mireille Guyot helps young people stay away from alcoholism and other attitudes or emotions deemed "hot," such as jealousy and anger (Londoño Sulkin 2004; Lucas 2019). However, my interlocutors clearly think that the recording and return of sound files contain the ability both to heal and to sicken. As is usual among the Bora, all will depend on the care

8. Research center attached to the LESC (UMR 7186), at the Universite Paris Nanterre.

9. The material can be accessed upon request (see infra) at the following websites: https:// archives.crem-cnrs.fr/archives/collections/CNRSMH_I_2016_037/ and https://archives. crem-cnrs.fr/archives/collections/CNRSMH_I_2016_038/, accessed 23/11/2020. 
and precautions taken by those responsible for maintaining the community's well-being. This dual capability became evident in the ten or so home-to-home appointments I made for the delivery of the memory cards and flash drives, although it was also manifest in the final meeting when we collectively evaluated the process, and the Bora deliberated on future access to the material and its possibilities of distribution.

\section{Sound and presence}

As the Bora live widely spread over a vast territory, before distributing the copies to each family, I agreed with my interlocutors the best schedule for the visit. When I arrived at the malocas, I always met some people who had already taken the day off. I brought with me food and tobacco, as well as my computer, the electronic storage devices, and a small portable speaker. After we talked a little about how files were organized, we listened to what they were most interested in, always with the help of a list left by Guyot with some information about the songs and narratives. From that information, my interlocutors confirmed if Guyot's notes regarding the authors of the records and some relationships between songs, rituals, mythological narratives, etc., were correct. During these meetings, which generally lasted a few hours, I was very interested in better qualifying the data concerning the records. However, I was also especially attentive to the multiple reactions that arose from listening to the material.

First, in possession of the inventory that indicated some sets of songs according to their corresponding rituals, everyone was interested in locating which records corresponded to the rituals they considered most "happy," "exciting," or "with more beautiful songs." Once they identified to which ritual the song belonged and, when possible, who the singers were, they often chanted the songs together or even stood up so that I could learn the dancing steps associated with a particular song. Toner noticed a similar reaction among the Yolngu in Australia in the course of a sound repatriation activity:

[...] memory is frequently an embodied phenomenon. Yolngu did not only sit quietly and reflectively when they listened to the old recordings - although many did-but sometimes adopted a physically active response that was an important aspect of their recollection. It was not uncommon for women, and sometimes men, to get up and perform the appropriate dance in accompaniment to the songs being played, or more commonly to perform the hand movements of the dance. Similarly, tapping along to a clapstick accompaniment or singing along to the words of a song was also a common response. (Toner 2003, p. 13)

Indeed, among the Bora, I noted that listening to the songs was, to borrow Toner's expression, "an embodied phenomenon." This reaction accompanied not only the "happy" and "beautiful" songs but also songs and healing speech-chants 
related to rituals nowadays considered violent. ${ }^{10}$ The same happened when they identified very close relatives or ancestors who possessed remarkable shamanic knowledge. On such occasions, there were frequent comments such as "this is my mother," "this uncle of mine, he was a brujo," 11 or "it seems that he is alive, here by my side." I then realized that my interlocutors adopted a much more reclusive and reflective posture at these moments. Sitting and with their heads bowed down like the chiefs at the nightly meetings in the malocas, they used to light improvised cigars and to consume large quantities of tobacco paste mixed with vegetable salt ( ambill $^{12}$ ).

Tobacco, for the Bora and other People of the Centre, is an essential substance. Besides being present in various mythical narratives of the origin of the world and being itself the creator of the "true humans" (Londoño Sulkin 2004; Echeverri 2015), its consumption is strictly related to actions of prophylaxis and protection. But what did the Bora protect themselves from by consuming tobacco while listening to the old recordings? To answer this question, we should assume that sounds captured by devices such as analog and digital recorders, when stored in media such as magnetic tapes or electronic devices, become "sound images" (Bayle 1993; Iazzetta 2016) that present similarities to visual and audiovisual images like photos or videos.

Generally, the Bora present no restrictions on being photographed. On the contrary, they keep several recent and old photographs in their homes (or, more recently, on their mobile phones and computers). Some of these photos hang on the wooden walls of their homes, and others are on the Facebook profiles that several of my interlocutors feed with posts about their community's most relevant events, birthday messages, wedding parties, short ritual videos, etc. However, more than once, I was surprised by some pictures of dead people. On these occasions, my interlocutors narrated the whole process of their relative's demise, using photos of people convalescent or already dead on hospital stretchers and in wooden coffins. I had difficulty understanding this practice until a prominent leader (who had also been Mireille Guyot's translator) suddenly

10. The healing speech-chants, known as "benzimentos" among the indigenous peoples of the Brazilian Upper Rio Negro (in Spanish, oraciones; in Bora, lluuvajit), are used in the treatment of diseases or as prophylactic measures (Buchillet 1987). Of very restricted circulation, in most cases they are transmitted against payment. Their effectiveness usually depends on the concomitant use of tobacco in paste or in cigars.

11. Brujo is a word used in regional Spanish to refer to the apíchoóbe, ancient Bora shamans who established direct contact with the animal masters. On this subject, see Lucas (2019, p. 135-140).

12. Máánií (or, in regional Spanish, ambil) is a paste substance obtained by cooking tobacco leaves in a clay or iron pot on firewood. Once sufficiently thick, the mixture is filtered and mixed with vegetable salt extracted from a wide variety of palms. It is also combined with some substance that confers viscosity to the paste, such as the gum of cacaurana or maraca (Theobroma bicolor Humb. \& Bompl). 
died. The next day, one of his nieces told me that she was still very afflicted because, since her uncle had died in a remote community, she had seen nothing that could really help her understand that the man was gone. Two days later, after receiving on her phone a picture of her uncle taken a few minutes after his death, she told me that she had calmed down and stopped crying or feeling sad. At the same time, I was also advised not to lament too much, so that the deceased would quickly find his way into the post-mortem world. ${ }^{13}$

I then understood that the photographs taken shortly after death are a kind of specific static visual image. One of their effects is to highlight the irreversible immobility of these bodies, pacifying the living, who finally stop mourning the departure of their relatives. The storage of these images in physical or virtual albums allows the process to be repeated as many times as necessary. Consequently, neither will the living wish the return of their deceased relatives nor will the dead be called back to their former homes. ${ }^{14}$ In the case of listening to the records involved in the repatriation of audio files, there is, therefore, a crucial difference: the presence evoked by sound does not provide any visual proof of the inactive condition of the deceased's bodies. Instead, listening to the records presents to the audience sound images in which the dead and their bodies find themselves, once again and through their voices, animated. Even if the Bora do not doubt the veracity of the death of these singers and consider such sound images as "representatives of a certain moment in time" (Nannyonga-Tamusuza and Weintraub 2012, p. 207), they do not ignore how they bring out a particular presence. This is similar to what is indicated by Treloyn, Martin, and Charles (2016) when the authors compare the status of human remains taken from their original communities with sound recordings:

[...] 'death has not altered their subject status. And as was the case when they were living and breathing, they can still expect to connect with, and reside within, their ancestral country'. Like bones, recordings are not the objective relics of past research, but rather are subjective remains of ancestors with which living people have active responsibilities and relationships. (Treloyn, Martin, and Charles 2016, p. 98)

Consequently, listening to the Fonds Guyot's songs also encouraged the Bora to engage in relations with some of their former relatives and, in particular, with a specific type of dead person. Although Guyot made several recordings with young people (some of whom still live on the Igaraparaná River), the records my interlocutors proved most cautious with were precisely those featuring the voice of singers with prestigious names and inherited chief positions.

13. For a similar and more complete analysis, see the Warao case presented by Allard (2013).

14. Apart from a film recorded by Gasché (1982) in the 1970s, I never had the opportunity to watch videos of their deceased relatives with my interlocutors. A future investigation on this subject may prove interesting, given the specificity of this dynamic type of images. 
These people, after death, are part of the clanic ancestors' group whose first-born children and grandchildren are their direct heirs and successors (Guyot 1972, 1975; Lucas 2019). Owing to the status, the knowledge, and the ritual prerogatives transmitted to them throughout their lives, these ancestors commonly established many relationships with beings who are outside the circle of daily human interaction. In general, the ancient chiefs were shamans who attacked their enemies with the help of animal master spirits. Nowadays, the chiefs are more concerned with the healing and protection of humans, which require a direct relationship with the tobacco spirit and other vegetable substances. In both cases, the chiefs are known to master a very "deep" knowledge.

Moreover, unlike most people, the chiefs, when they die, do not go definitively to the world of the dead, but remain in their original malocas as the spirit-mentors of the present chiefs. Although they are not visible, the place they occupy produces a specific type of relationship. While they are often called upon by chiefs who wish to know how to conduct a conflict or treat a patient, it is also crucial that these ancestors are not thwarted or disrespected, at the risk of punishing with diseases those who (intentionally or not) confront them.

Martini considers that the process of repatriation of ritual artifacts in the Upper Rio Negro was a way of "digging up the dead" (2012, p. 340). In a similar vein, I quickly realized that in the case of the prestigious chief-singers, the reverse funeral evoked by the return of the sound archives required shamanic skills in prophylaxis and healing that were capable of "cooling down" possible misfortunes for the listeners. Therefore, it became unanimous among my interlocutors that, before interacting with that material, it was necessary to master a kind of shamanic knowledge that went far beyond the mere ability to memorize or perform songs. It was only after this period of socializing the records with each family that we held a final meeting on the subject. On that occasion, the discussions turned specifically on access arrangements which would apply to the material.

\section{Access arrangements}

Before we go any further, we should understand a little more about the songs and their modalities of transmission. I will deliberately leave out a detailed description of the oraciones or benzimentos, i.e., the speech-chants used in healing therapies. Although I have, on various occasions, been allowed to observe local shamans perform them close to their patients' bodies (or close to the vegetable substances used in their therapies), I have never been authorized to record them or transcribe their contents. Because the Bora argued that the registering of these healing speech-chants could be dangerous for me, for the patients and the performers, this interdiction has become part of the research arrangement with my interlocutors. However, I had the opportunity to learn and 
record several other musical expressions performed with or without instrumental accompaniment (drums, flutes, and other wind and percussion instruments). Regarding the songs specifically, although there are some lullaby and ocarina songs, ${ }^{15}$ the vast majority of them are directly related to one of the over ten rituals performed today (Lucas 2019, p. 291).

The Bora rituals can be either "ordinaries"16 (wahtsi) or "titulars"17 (meméva wahtsi). ${ }^{18}$ While the former are carried out at any time and by any maloca master, the latter are performed only by those who have the required ritual prerogative. Furthermore, it is in the course of these "titulars" (also known as "naming rituals") that the intergenerational transmission of prestigious names take place, marking the nobility (miaáte) ${ }^{19}$ of certain first-born people (among whom are the aforementioned maloca chiefs). ${ }^{20}$ In both cases, the rituals are performed in the patriclanic malocas and depend on the existence of two groups (hosts and guests) closely related through their chiefs, who usually remain each other's ceremonial partner throughout their lives. After the radical demographic decline of the early 20th century (Taussig 1987), the ceremonial partner of a maloca host now commonly belongs to another group of the People of the Center, such as the Murui-Muina or the Muinane. ${ }^{21}$

Guests are responsible for providing the game for the hosts and, at the same time, for performing the vast majority of the chants during the rituals. These songs, in turn, are divided into at least four closed suites (i.e., opening songs, diurnal songs, evening songs, and sunrise songs) that differ from each other in rhythmic and melodic aspects, besides being associated with different choreographies. ${ }^{22}$ In addition to the opening and closing phases of the ritual,

15. The Bora ocarinas are globular aerophones made of clay, seeds, resin, or beeswax. They usually have a hole for air entry and four for fingering. They are performed by men at sunrise or in the late afternoon, with no direct relation to the rituals or healing therapies. The melodies are memorized through songs whose lyrics accompany the sound performed on the instrument.

16. In regional Spanish, ordinarios.

17. In regional Spanish, titulares.

18. Literally, the "naming dance ritual."

19. In Bora, "the nobles."

20. For the reader familiar with Amerindian literature, this is a similar difference to that between "Dabucuri" and "Jurupari" rituals among the peoples of the Upper Negro River (Hugh-Jones 1979; Journet 1995).

21. It is important to take into account that most of the Bora rituals find equivalents among the other peoples of the region.

22. In the rituals I attended, which generally lasted from late afternoon until morning, between 50 and 70 different songs were performed. The hosts sing only one song from the entrance and sunrise suites. In the case of "titular" rituals, there is a suite (llééneba) of only two songs performed both by hosts and by guests. Ideally, its lyrics are part of the few that are open to improvisation within the set of Bora ritual songs. There are also songs performed 
the execution of the songs usually follows the same pattern. In the outside patio of the maloca, a man from the guest group reflects on his repertoire and chooses a song associated with the ongoing suite. Then, he enters the main door, and soon other men follow him and stay in line at his side. After singing the opening verses of the song for the first time, his partners follow him vocally. A few moments later, one of the women attending the ritual positions herself in front of the group. She must belong to the group of guests and is usually the wife or daughter of the main singer. Quickly, other women join her, and together they accompany the male group through onomatopoeias elaborated from the last phonemes of each verse of the song. ${ }^{23}$

All of these songs, when in the Bora language, make metaphorical references to mythical episodes whose meaning is usually revealed only by someone with a broad mastery of such narratives. ${ }^{24}$ Most of the time, the songs evoke, through these metaphors, spirits or owners of the animals that are much more dangerous and feared than the deceased chiefs mentioned above. As animals are human predators, it is quite normal for the Bora to be concerned about the possibility of an animal attack. In this sense, rituals become especially delicate moments since the vast majority of songs repeatedly name animals that can be irritated by being evoked in the malocas of their human enemies. A cautious host, knowing which ritual he will promote, and which animals will be named in the corresponding suites, will take the necessary precautions in advance and will not allow inappropriately performed songs. When there are guests from other groups of the People of the Center, some songs will be performed in foreign languages. Although there are small variations in the songs performed by people affiliated to the different Bora clans, in these occasions the host must be especially able to recognize the dangers that come from the foreign songs. ${ }^{25}$

Thus, following the classification proposed by Fausto, Franchetto, and Montagnani (2011), the Bora have a fixed musical repertoire transmitted

by the hosts before the entrance suites, in order to make the guests drink the manioc beverage offered by the owners of the ritual. For a formal analysis of the choreographic movements carried out in the Murui-Muina dances, see Garcia (2018).

23. In a remarkable way, this description is in evident conformity with the propositions of Menezes Bastos (2007) about the "sequentiality" and the "nucleus-periphery" relationship of Amerindian music.

24. The songs of the rituals Méémeba and Ujcútso have no apprehensible semantic meaning for the Bora. They are related, respectively, to the language of the animals and the Carijona, a Carib group of the Caquetá region with whom the Bora used to wage war in the past. These songs also are distinguished by the fact that, throughout these rituals, only one woman accompanies the singing group vocally (although the others remain by her side and perform the choreographies).

25. This becomes especially relevant if we consider that, in the case of foreigners from other People of the Center, it is not only the songs that vary but also the mythical narratives and the healing speech-chants that are associated with them. 
intergenerationally. In this "cumulative system," occasional improvisations and variations are seen as "mistakes in the transmission process" (p. 42). In this sense, the Bora are closer to the peoples of the Upper Xingu than to those who, like several Tupi peoples, operate mainly according to a "generative scheme" (ibid.) in which the songs emerge from autobiographical and oneiric experiences and are executed ritually just once. Among the Bora, as well as in the Upper Xingu, ritual songs ideally should be learned and performed without variations and according to previously ordered suites. Such a fact highlights a fundamental point: the song's transmission always depends on the existence of a master-apprentice relationship. ${ }^{26}$

Micarelli, reflecting on "indigenous epistemologies" based on her experiences with the Muinane and the Murui-Muina, states that the People of the Centre conceive knowledge as something "given." Thus, among these peoples, it would not be possible to build or create new knowledge, but only to find it through a particular "personal search" that is rooted in a specific relationship between those who teach and those who learn:

Accordingly, knowledge transmission is typically nonintrusive and it deliberately avoids direct didactic explanations. However, knowledge transmission among the People of the Center is far from being unarticulated. Support for learning is meticulously organized, and sophisticated pedagogical strategies foster a learner's heuristics, alert perception, and capacity for introspection. Ambiguity and dissimulation are key pedagogical tools; by displacing finite solutions, they engender a constant questioning and push the apprentice to keep up the search. (Micarelli 2015, p. 79)

The Bora pedagogy, as observed by Micarelli for other People of the Centre, also avoids a manifest methodological approach: deliberately, people should learn without saying that they are learning. In this vein, a young man who wishes to master a vast repertoire of ritual songs will come close to an older man and follow him night after night in the nocturnal sessions of the mambeadero. ${ }^{27}$ Even if they are close relatives, the youngest will work for the eldest, i.e., he will go to the gardens to collect coca leaves and then toast, pound, and filter them

26. Far from this being a more contemporary condition of the Bora ritual dynamic, such a relationship dates back to mythical times, when two brothers learned all the ritual songs from the Jaguar-of-the-Chants, a character that condenses in itself a series of references to affinity (Lucas 2019, p. 317).

27. The mambeadero (regional Spanish word) is a nocturnal ritual space where the men gather. Daily, the sessions of the mambeaderos are occasions for the discussion of community issues, myth narration, and the healing of patients. Usually, small benches are arranged in a circle inside the maloca. The only places marked are the chief's seat (always placed on one of the four maloca struts) and the benches reserved for one or two of his privileged interlocutors (usually other chiefs or maloca masters who, due to their age and social position, have the prerogative of speech). 
until the mambe is ready. ${ }^{28} \mathrm{He}$ will also have to ensure that there are enough Cecropia leaves for the mambe production and a sufficient amount of tobacco and vegetable salt for the preparation of the ambil. Meanwhile, the older man (who is often a maloca master named in a "titular" ritual) remains seated on his bench, from where he conducts the session and organizes the order and content of the participants' speeches. Sometime after the beginning of the meeting, he takes the word for himself and, using a specific verbal art, recounts the origin of the most varied kinds of things, beings, and behaviors. Such narratives are very often intersected by songs from the suites of some rituals and by healing speech-chants. Together, these contents form a "deep knowledge" (páñé), held by the Bora as "principal," "true," or "complete."

When the objective is to master only a particular group of songs (or healing speech-chants, or mythical narratives), it is common for the apprentice to come close to a sage with a good amount of mambe and ambil. Just as hosts do to guests in rituals, he will use such substances as payment for the content he wishes to acquire. ${ }^{29}$ It seems, however, that this is a "less profound" way to access knowledge. Without the knowledge about the relationship between song, myth, and healing therapy, the possibilities of using this content will be much more limited. In fact, even with a generous payment, it is unlikely that a sage will be ready to share his "deep" knowledge with an eventual apprentice. That is why when someone has only offered material retribution instead of daily living and working with the sages, it is common to hear that such a person only dominates this content superficially or, in Spanish, por encimita, no más.

Giving access to sound recordings can therefore be a radical way of modifying the "depth" of the transmitted knowledge and, subsequently, the relationships between master and apprentice. It is similar to what Fausto observed among the Kuikuro in the Upper Xingu:

The advent of tape recorders some decades ago enabled a new mode of transmission: recording an unrelated singer resident in another village, who is paid immediately with goods promised beforehand. Thus any long-term involvement or risk of being "deceived" is avoided. Singers are often heard saying that they do not teach young people today because the latter do not ask them; the youth in turn

28. The mambe is an exclusively male substance, prepared and consumed daily in mambeaderos. In Portuguese, the term is ipadu (Upper Rio Negro) or padu (Middle Solimões). After the coca leaves (Erythroxylum coca var. ipadu) are roasted, they are macerated in a wooden pestle and mixed with the ashes of embaúba or yarumo leaves (genus Cecropia). The resulting powder is then filtered through a thin cotton bag with a wire structure. Finally, the substance is distributed by the maloca master to the people present in the mambeadero, who store it in their small bottles.

29. In the case of rituals, the songs performed by the guests are always paid for by the hosts with vegetable food (fruit and cassava drinks, cassava breads, etc.), besides mambe, ambil, and vegetable salt. 
say that they feel ashamed and are afraid to commit themselves to a master and become entangled in a cycle of learning and debt payments they might be unable to meet. The tape recorder allows them to "equalize the account" immediately, transferring to tape the lengthy relation with a master and his or her expectations. (Fausto 2016, p. 144)

The Bora today, just like the Kuikuro, offer material retribution for recordings made with old sages outside the rituals, and the same is true for anthropologists and other researchers. Nevertheless, the return of sound files introduces a specific type of rupture, since there is no daily working relationship or any different possible payment to the singer, who, in many cases, has already passed away. This subject, together with the complex presence of the dead discussed above, surrounded my interlocutors' discussions (with me and among themselves) in the first half of 2017. In July of that same year, we held two meetings to formally discuss the matter (one during the day, at the community house, and the other at night with the sage men).

Before starting the process of the Fonds Guyot's sound repatriation, I thought that the main demand of the Bora would be barring access to non-indigenous people. At that point, I was already used to hearing complaints about nonindigenous people who, in possession of audiovisual recordings made in the malocas, conducted a wide range of illegitimate acts, from academic investigations to neoshamanic healing sessions. The Bora, in these situations, were bothered by the fact that they did not have the slightest control over the records' use and circulation outside their malocas. I was surprised, however, to find that this was only the starting point of the discussion. As I had suspected, the Bora demanded that non-indigenous people who wanted access to the recordings first make contact with the maloca chiefs and other local authorities so that, together, the communities could deliberate on the case. Nevertheless, on that occasion, they agreed that the same conditions should also apply to the Bora who live temporarily or permanently away from their original malocas. The text (in Spanish) of this agreement on access to the Fonds Guyot's audio data can be found below. It has been signed by the sages' representative (Fernando Jifichiu), the "ethnic coordinator" (Roy Alex Teteye), and the governors of the cabildos Petani, Providencia, and Providencia Nova (respectively, James Kuguao, Alejandro Teteye, and Matilde Giagrekudo).

\section{Acuerdo sobre el acceso al material sonoro del Fonds Guyot}

Reunidos en la sede de la escuela Santo Domingo Savio, los Gobernadores de los cabildos de Providencia, Providencia Nueva y Petani, los ancianos y el Coordinador Étnico en ejercicio se pusieron de acuerdo que el acceso al material sonoro disponible en internet en la página web del CREM/LESC permanecerá restricto a las personas que, por medio del aval escrito y firmado del Coordinador 
Étnico (quien a su vez consultará los gobernadores y los ancianos), tengan la autorización de dicho dirigente. El aval del Coordinador Étnico se expedirá en respuesta a una solicitud formal que debe ser enviada presentando los motivos del interés de la consulta del material y sus intenciones de utilización futura. Tal medida busca garantizar el control a los que puedan acceder al material y al uso que harán del mismo.

The justification for such an interdiction was always the same. From the point of view of the malocas' chiefs and young local leaders, there are many cases in which some Bora, while living in their original communities, show little interest in "traditional" life. That is, they do not commit themselves to learn the Bora language (currently endangered by the massive presence of Spanish), they do not sit with the sages in the mambeaderos, they do not help in the work of the coca and tobacco production, etc. With the desire to migrate and to establish themselves in the big cities, they complete their secondary education and go to universities. Once admitted to higher education institutions, they are compelled by colleagues and teachers to prove their indigenous identity through the use of the native language and attitudes that, especially in the eyes of non-indigenous people, would be demonstrations of their culture. This would also happen to those who, even without being affiliated to universities, obtain work contracts for the State and NGOs or independently offer shamanic healing sessions to non-indigenous people in Bogotá, Medellin, or Leticia. ${ }^{30}$ Regarding the access of other People of the Center, at no point was the possibility envisaged of these records being used in local rituals, since the idiomatic difference makes it unusual for the Bora songs to be performed by their neighbors. However, the same concern remained that young people from other groups, living outside their malocas, could use these recordings in urban contexts.

Therefore, my interlocutors consider that sound recordings of ritual songs and mythical narratives could be misused by indigenous people who no longer live in their home communities. Furthermore, by homogenizing an originally heterogeneous network of rights that encompasses such contents (Carneiro da Cunha 2009), the free circulation of these archives has the potential to generate unwanted effects. The need to control the flow of this information is therefore partially based on the fact that the knowledge is transmitted through digital files without having been appropriately reciprocated, either with work or with material goods. Nonetheless, still according to the same discussions stimulated by the repatriation activities, the Bora perceive this kind of debt as only part of the problem. On the one hand, sound recordings that lack complementary information that gives them meaning and effectiveness are, as one elderly

30. With regard to these admonitions, I have not yet had the opportunity to learn in detail the opinion of the young Bora who live in the cities. 
woman told me once, "pure poetry." On the other, such records can unleash illnesses in these young Bora and their relatives.

Although I did not privilege the sound recordings during my fieldwork, on some occasions (such as in important rituals or community meetings), the Bora asked me to record their music and narratives. However, it was always preceded by an encounter with a shaman who blew tobacco smoke through my body and prepared small "healed" cigars for me. My Bora friends considered this a means of safeguarding me from any possible "malignity." That danger arose because the animals and spirits evoked in these records would become annoyed with my work and, if I were not protected, would attack me. Following this same logic, the young men who live far from their communities and have little or no "deep" knowledge about the Fonds Guyot records are at risk of being attacked by animals and spirits. These beings, unaware of those who listen to or perform the songs, would send diseases to them and to their families. Thus, the interdiction of access, which at first sight might appear to be mere avarice, is in fact a double means of caring. In the first place, it avoids putting young people who live in urban environments in situations they will not know how to deal with alone. At the same time, it ensures that the relationship with and between the malocas, as well as what is considered the correct way to transmit knowledge, are not endangered by the introduction and the uncontrolled circulation of records.

\section{Preliminary conclusions}

At the beginning of 2018, almost a year after the sound repatriation of the Fonds Guyot files, I returned to Igaraparaná. The year before, I had left the villages with a feeling of uncertainty. Despite the initial enthusiasm of my interlocutors with the microSD cards and the flash drives, I could not know about the use and destiny of these small and fragile objects in the short and medium term. When I arrived, I went directly to the maloca of the Giant Anteater clan, where the chief and his people were preparing a ritual.

As I approached the maloca, I heard a voice I could not recognize singing alone a song of the Ujcutso ritual, which would take place the next day. On entering, I saw more than a dozen men seated in the mambeadero around a huge speaker that worked with the help of a rarely used light generator. The equipment was in the place commonly occupied by the ceramic plate used in the burning of the Cecropia leaves needed to produce mambe. Usually, the location of this artifact is referred to as the "navel" or "center" of the maloca and it is mentioned in many mythical narratives.

I then realized that I did not recognize the singer's voice because it was a recording made by Mireille Guyot with a former and prominent Bora chief. The posture of the audience, concentrated and seeking to follow vocally the song 
recorded, called to my mind a myth that I heard from the chief of the Sunrise clan. He narrated this episode to me one morning in 2016, while we walked along the footpath that separates the communities of San José and Providencia. Here, I reproduce it according to notes I made later in my field notebook.

A man went to the bottom of the river. There, the Anaconda-of-Drums showed him everything he had but forbade him to tell what he had seen. The man returned with mambe, ambil, a mortar and a pestle for the coca leaves, among other things. The people who came to visit him asked about what he had seen, but he said nothing. Over time, they took everything he had, leaving his maloca empty. There was always a white man asking him what he had seen under the water. He kept silent, and this white man offered him many things as payment until the host could no longer resist and told him what existed in the underwater world. At that moment, the river water began to rise rapidly, flooding the maloca. The two men lodged as they could in the interior part of the maloca roof, when then the Anaconda-ofDrums wrapped it, shaping its body around the house like a ring. They could not see where its head was, so they decided to cut the Anaconda-of-Drums into three parts. The part closest to the head gave rise to the manguarés, a pair of talking drums present in all the malocas. The middle part of its body gave rise to the llaariwa, a drum of large proportions owned by the most prestigious chiefs. Finally, the section closest to the tail has originated all the equipment of the whites that emit sound, such as radios, speakers, mobile phones, televisions, etc.

The myth above does not directly address the theme of the "bad choice," but it displays a certain similarity with that described by Hugh-Jones (1988), in which the Barasana obtain the bow, while the Whites acquire the rifle. ${ }^{31}$ In this direction, the Bora narrative does not provide information regarding why they were endowed with the drums rather than with the electronic devices. However, what calls our attention is that, here, the ritual artifacts (drums) appear, since their primeval origins, related to the obviously contemporary electronic devices with which my interlocutors are increasingly familiar. The scene of the men seated in the mambeadero (par excellence, the privileged place for the transmission of knowledge and the conduction of shamanic therapies) around a huge speaker and its association with the myth of the origin of audio reproduction devices was, in some way, the confirmation of an old intuition: namely, the perception that very often the Bora are more concerned with the correct way of carrying out or reproducing relations than with the invariability of the material and aesthetic vehicles used for this purpose.

Nowadays, a Bora chief can give a long speech on the centrality of coca and tobacco equipped with deteriorated plastic cocoa powder bottles filled with

31. This theme of the "bad choice" appears in several Amerindian myths about the origin of the separation between indigenous and white peoples. As noted by Viveiros de Castro (2001), such a theme can be read as a transformation of the "short life" myth about the origin of mortality (Lévi-Strauss 1964). 
mambe and ambil (rather than with traditional containers, made of gourds adorned with graphic motifs). Likewise, the occasion on which the songs echoed in the speaker was considered by my interlocutors as an adequate or "deep" way of transmitting knowledge. On the eve of a ritual, in the mambeadero and with the proper precautions regarding the deceased singer, the Bora had access to songs that were about to disappear even in their current most renowned sages' memory. ${ }^{32}$

Analyzing the publication of books with mythical narratives of the Upper Rio Negro (a cultural complex in the Northwestern Amazon that resembles in many ways the Caquetá-Putumayo region), Hugh-Jones states that "in a certain sense, the publication of these sacred stories can be considered as the transformation of an old form of diffusion" (2010, p. 216). According to the author, this material conceived and elaborated by the indigenous people themselves presents transformations aligned with native concepts regarding material and immaterial knowledge (and its transmission regimes) that precede the arrival of these new technologies or objects.

Transformations of this kind do not cease to occur in indigenous Amazonia. In July 2020, some young Bora created a WhatsApp group that today has more than 70 participants. The main purpose was to gather and disseminate information that would help them fight against the Covid-19 pandemic. In this regard, the group was specially conceived for those who live far from their communities or are in hospital treatment. Although hundreds of audio files have been uploaded in a short period of time, most records are contemporaneous and made over "ordinary" rituals. Therefore, more sensitive content such as healing speech-chants, naming ritual songs, or Mireille Guyot's old records are left out, in consonance with the patterns we have seen so far in song repatriation activities.

Thus, it becomes clear that the media employed for digital sound repatriation can be either a resource for the revitalization of endangered practices or a threat to their continuity. Obviously, all the community meetings on the subject must be based on the essential and necessary consultation guidelines and prior consent. In addition, the intermediaries in the process (especially the non-indigenous ones) must be sensitive to the possible consequences of the return of materials separated from their communities of origin for a long time. Such sensitivity, in turn, depends directly on a minimal understanding of what we might call, in very simplified terms, local cosmology and sociology. If we think about the issues that arose from the Bora songs' repatriation, we note that it was fundamental to take into consideration some aspects of native

32. A few days later, I accompanied the Bora in a great Murui-Muina ritual. To the surprise of several people present, some Bora men, as guests, entered the maloca with the game they would deliver to their hosts. Then they chanted songs no longer sung, but that were quickly identified, by the women who were with me, as part of the recordings made by Guyot. 
eschatology and pedagogy. Only then were we able to understand, at least initially, specific effects of the return of the material and its double capacity to cause both "healing" (Simpson 2009) and illness in those who access it.

Later in 2018, two young Bora living in Bogotá contacted the local authorities to request access to the songs available in the CREM online database. One of the cases was quickly discussed, and access was granted under the justification that this young man, when he was living in his maloca on the Igaraparaná, always sought to participate in community life. Regarding the other request, although I have mentioned a few times to the local leaders the necessity to discuss and deliberate the subject, no decision has been taken until today. Informally, some people told me they did not agree that this young man should have access to the material. They were concerned about its use and criticized the fact that he was not really interested in establishing long-term relationships with the sages or maloca chiefs. Somehow, the refusal (even if informal) and the admission to access the archives, combined with the discussions presented in this paper, led us to believe that repatriation actions can be unique opportunities not only to generate new data about old audio recordings, but also to deal with the impact of new technologies, to learn more about native ways to learn and transmit knowledge, and, indeed, about specific kinship and political relations and ritual practices.

As we have seen, for the Bora, the knowledge in question (ritual songs, mythical narratives, and healing speech-chants) should not exist outside of a relationship between master and apprentice. Ideally, as we have also noted, this relationship should take place in the mambeadero space and surrounded by certain behaviors and interdictions. Therefore, one of the dangers of the transformation of this knowledge in online and digital files is what we could understand as a passage from a mode of transmission of knowledge marked by the economy of the gift to another, notably Euro-American, related to the economy of the commodity. While in the world of the gift, the priority is the creation, maintenance, and expansion of social relations, the world of the commodity concentrates on the accumulation of goods (Strathern 1988, p. 222). In this case, such goods may be the audio records, transformed into sterile information, dismembered from their holders or owners, and consequently from their relations of transmission. After all, the listening and circulation of songs stored and reproduced in electronic devices do not require the physical presence of those who previously chanted or recorded the material.

When we take into account the assumption that in the world of the gift there is an intrinsic relationship between producer and product (or, here, between knowledge and the sage or master), the danger of the uncontrolled dissemination of digital files in the fashion of a commodity economy is that the knowledge becomes a "thing." Hence, it would no longer generate a specific type of social master-apprentice relationship that is indispensable for the transmission of 
knowledge considered correct and innocuous. Thus, the uncontrolled circulation of ritual songs on the Internet or through electronic storage devices could, according to my interlocutors, endanger the very existence and effectiveness of these songs. At the same time, in certain situations it can contribute to the recovery of lost or endangered content. From this perspective, in the future, it would not be unreasonable to combine these contrasting considerations with an investigation on the relationship between current repatriation actions and anthropology (or ethnomusicology) as "cultural critique" (Marcus and Fischer 1999). Accompanied by the just and severe native critics, self-reflection on the Euro-American obsession with recording, accumulating, and conserving a large amount of data and objects may finally serve as an important motivating factor for a responsible development of these activities.

* Manuscrit reçu en janvier 2020, accepté pour publication en octobre 2020.

\section{References cited}

Allard Olivier

2013 "To cry one's distress: death, emotion and morality among the Warao of the Orinoco Delta," Journal of the Royal Anthropological Institute, 19 (3), p. 545-561.

AMEs Michael

1992 Cannibal tours and glass boxes: the anthropology of museums, UBC Press, Vancouver.

Appadurai Arjun

1988 "Introduction: commodities and the politics of value," in Arjun Appadurai (ed.), The Social Life of Things. Commodities in Cultural Perspective, Cambridge University Press, Cambridge.

BAYLE François

1993 Musique acousmatique. Propositions, positions, Institut national de l'audiovisuel, Bry-sur-Marne/Buchet-Chastel, Paris.

BuChillet Dominique

1987 “'Personne n'est là pour écouter.' Les conditions de mise en forme des incantations thérapeutiques chez les Desana du Uaupès brésilien," Amerindia, 12, p. 7-32 [English version: "Nobody is there to hear: Desana therapeutic incantations," in Jean Langdon and Gerhard Baer (eds), Portals of Power. Shamanism in South America, University of New Mexico Press, Albuquerque, 1992].

CARneiro da Cunha Manuela

2009 Cultura com Aspas e Outros Ensaios, Cosac \& Naify, São Paulo.

Cesarino Pedro

2019 "Divergence technologique. Chamanisme et numérisation en Amazonie," Gradhiva, 29, p. 162-187.

ECHEVERRI Juan Alvaro

1997 The People of the Center of the World. A Study in Culture, History, and Orality in the Colombian Amazon, New School for Social Research, New York. 
Digitization, return, and circulation of sound recordings among the Bora

2015 "Cool tobacco breath: the uses and meanings of tobacco among the people of the Center," in Andrew Russell, and Elizabeth Rahman (eds), The Master Plant. Tobacco in Lowland South America, Bloomsbury Publishing, London/ New York, p. 107-130.

Есно-Hawк Roger

2002 Keepers of culture. Repatriating Cultural Items under the Native American Graves Protection and Repatriation Act, Denver Art Museum, Denver.

Fausto Carlos

2016 "How much for a song? The culture of calculation and the calculation of culture," in Marc Brightman, Carlos Fausto, and Vanessa Grotti (eds), Ownership and Nurture. Studies in Native Amazonian Property Relations, Berghahn, Oxford, p. 133-155.

Fausto Carlos, Bruna Franchetto, and Tommaso Montagnani

2011 “Art verbal et musique chez les Kuikuro du Haut Xingu," L'Homme, 197, p. 41-70. Gabus Jean

1975 Amazonie nord-ouest, Musée d'ethnographie de Neuchâtel, Neuchâtel.

GARCIA Oscar Ivan

2018 RAFUE ITE! Ethnographie d'un bal rituel amazonien (Murui-Muina-Uitoto, Amazonie colombienne), Ph.D., social anthropology and ethnology, université de recherche Paris Sciences et Lettres, Paris.

GASCHÉ Jürg (dir.)

1982 Meemeba 1974, Fonds national suisse de la recherche scientifique, Neuchâtel/ CNRS, Paris, film $16 \mathrm{~mm}, 55 \mathrm{~min}$.

GASCHÉ Jürg

2009 "La Sociedad de la gente del centro," in Frank Seifart, Doris Fagua, Jürg Gasché, and Juan Alvaro Echeverri (eds), A multimedia documentation of the languages of the People of the Center, Online publication of transcribed and translated Bora, Ocaina, Nonuya, Resígaro, and Witoto audio and video recordings with linguistic and ethnographic annotations and descriptions, DOBES-MPI, Nijmegen.

Gasché Jürg, Alicia Lourteig, and Pierre Centlivres

1976 Culture sur brûlis et évolution du milieu forestier en Amazonie du nord-ouest, actes de colloque de l'Institut d'ethnologie de Neuchâtel [6-8 novembre 1975], Société suisse d'ethnologie, Bâle.

Gunderson Frank, Robert LANCEFIELD, and Bret Woods (eds)

2019 The Oxford Handbook of Musical Repatriation, Oxford University Press, Oxford. GuYoт Mireille

1972 "La maison des Indiens Bora et Miraña," Journal de la Société des américanistes, 61, p. 141-176.

1975 "Le système cultural Bora-Miraña," in Jean Gabus (ed.), Amazonie nord-ouest, Musée d'ethnographie de Neuchâtel, Neuchâtel, p. 93-109.

Heurich Guilherme

2018 "The shaman and the flash drive," in Richard Pace (ed.), From Filmmaker Warriors to Flash Drive Shamans. Indigenous Media Production and Engagement in Latin America, Vanderbilt University Press, Nashville. 
Hugh-Jones Stephen

1979 The Palm and the Pleaides. Initiation and Cosmology in Northwest Amazonia, Cambridge University Press, Cambridge.

1988 "The gun and the bow myths of White Men and Indians," L'Homme, 28 (106107), p. 138-155.

2010 “Entre l'image et l'écrit. La politique tukano de patrimonialisation en Amazonie," Cahiers des Amériques latines, 63-64, p. 195-227.

IAZETTA Fernando

2016 "A imagem que se ouve," in Gilberto Prado, Mônica Tavares, Priscila Arantes (eds), Diálogos Transdisciplinares. Arte e Pesquisa, Escola de Comunicação e Artes/Universidade de São Paulo, São Paulo.

Instituto do Patrimônio Histórico e Artístico Nacional (IPHAN)

2007 Dossiê Iphan 7. Cachoeira de Iauaretê. Lugar sagrado dos povos indígenas dos Rios Uaupés e Papuri (AM), Instituto do Patrimônio Histórico e Artístico Nacional, Brasília.

JAAKOLA Lyz, and Timothy POWELL

2019 “The Songs Are Alive': Bringing Frances Densmore’s Recordings Back Home to Ojibwe Country," in Frank Gunderson, Robert C. Lancefield, and Bret Woods (eds), The Oxford Handbook of Musical Repatriation, Oxford University Press, Oxford.

JOURNET Nicolas

1995 La paix des jardins. Structures sociales des Indiens curripaco du haut Rio Negro (Colombie), Institut d'ethnologie/Musée de l'Homme, Paris.

LANCEFIELD Robert

1998 "Musical traces retraceable paths: the repatriation of recorded sound," Journal of Folklore Research, 35 (1), p. 47-68.

LÉvi-STRAuss Claude

1964 Le Cru et le Cuit, Plon, Paris.

LONDOÑo Sulkin Carlos

2004 Muinane. Un proyecto moral a perpetuidad, Editorial Universidad de Antioquia, Medellín.

LuCAS Maria Luísa

2019 O Oriente e o Amanhecer. História, parentesco e ritual entre os Bora na Amazônia Colombiana, Ph.D., social anthropology, Programa de Pósgraduação em Antropologia Social, Museu Nacional, Rio de Janeiro.

MARcus George, Michael Fischer

1999 Anthropology as Cultural Critique. An experimental moment in the human sciences, University of Chicago Press, Chicago/London.

MarTini André

2012 "O retorno dos mortos: apontamentos sobre a repatriação de ornamentos de dança (basá busá) do Museu do Índio, em Manaus, para o rio Negro," Revista de Antropologia, 55 (1), p. 331-355.

McCoy Jason

2019 "Memory, Trauma, and the Politics of Repatriating Bikindi's Music in the Aftermath of the Rwandan Genocide," in Frank Gunderson, Robert C. 
Digitization, return, and circulation of sound recordings among the Bora

Lancefield, and Bret Woods (eds), The Oxford Handbook of Musical Repatriation, Oxford University Press, Oxford.

MELo Jorge

2010 Kàjrée: a vida social de uma machadinha kraho, Dissertação de Mestrado, Programa de Pós-Graduação em Antropologia Social da Universidade Federal do Rio Grande do Norte, Natal.

Menezes Bastos Rafael

2007 "Música nas sociedades indígenas das terras baixas da América do Sul: estado da arte," Mana, 13 (2), p. 293-316.

MicARELli Giovanna

2015 "Finding the taste of knowledge: the orphan in indigenous epistemologies," Tipiti. Journal of the Society for the Anthropology of Lowland South America, 13 (2), p. 74-89.

Nannyonga-Tamusuza Sylvia, and Andrew Weintraub

2012 "The audible future: reimagining the role of sound archives and sound repatriation in Uganda," Ethnomusicology, 56 (2), p. 206-233.

Peers Laura, and Alison Brown (eds)

2003 Museums and Source Communities. A Routledge reader, Routledge, London/ New York.

REED Trevor

2019 "Reclaiming Ownership of the Indigenous Voice: The Hopi Music Repatriation Project," in Frank Gunderson, Robert C. Lancefield, and Bret Woods (eds), The Oxford Handbook of Musical Repatriation, Oxford University Press, Oxford.

RuBEnSteIn Steven Lee

2007 "Circulation, accumulation, and the power of shuar shrunken heads," Cultural Anthropology, 22 (3), p. 357-399.

SARr Felwine, and Bénédict SAvoy

2018 The Restitution of African Cultural Heritage. Toward a New Relational Ethics, Ministère de la Culture/UMR 7220 (CNRS - ENS Paris Saclay - Université Paris Nanterre), Paris.

SEEGER Anthony

2019 "Archives, Repatriation, and the Challenges Ahead," in Frank Gunderson, Robert C. Lancefield, and Bret Woods (eds), The Oxford Handbook of Musical Repatriation, Oxford University Press, Oxford, p. 145-160.

SIMPSON Moira

1996 Making Representation. Museums in the Post-Colonial Era, Routledge, London.

1997 Museums and Repatriation. An Account of Contested Items in Museum Collections in the UK, with Comparative Material from Other Countries, Museums Association, London.

2009 "Museums and restorative justice: heritage, repatriation, and cultural education," Museum International, 241-242 (vol. 61, no. 1-2), p. 121-129.

STRATHERn Marylin

1988 The Gender of the Gift. Problems with Women and Problems with Society in Melanesia, University of California Press, Oakland. 
TAussig Michael

1987 Shamanism, Colonialism, and the Wild Man. A Study in Terror and Healing, University of Chicago Press, Chicago.

THRAm Diane

2019 "Music Archives and Repatriation: Digital Return of Hugh Tracey's 'Chemirocha' Recordings in Kenya,' in Frank Gunderson, Robert C. Lancefield, and Bret Woods (eds), The Oxford Handbook of Musical Repatriation, Oxford University Press, Oxford.

Treloyn Sally, Matthew Martin, Rona Charles

2016 "Cultural precedents for the repatriation of legacy song records to communities of origin," Australian Aboriginal Studies, 2016 (2), p. 94-103.

TONER Peter

2003 "History, memory, and music: the repatriation of digital audio to Yolngu, or, memory as metadata," in Linda Barwick, Allan Marett, Jane Simpson, and Amanda Harris (eds), Researchers, communities, institutions, and sound recordings, University of Sydney Press, Sydney, p. 2-17.

VALDOVINOS Margarita

2017 "Cilindros de cera en la Sierra Madre Occidental: el diálogo en la retribución de los archivos sonoros de K. Th. Preuss a los náayeri del Occidente de México," Música em Contexto, 1, p. 219-235.

Viveiros de Castro Eduardo

2001 "Os termos da outra história," in Carlos Alberto Ricardo (eds), Povos indígenas no Brasil: 1996-2000, Instituto Socioambiental, São Paulo, p. 35-40. 